http://ojs.stikes-muhammadiyahku.ac.id/index.php/herbapharma

\title{
FORMULASI SPRAY GEL ANTI LUKA DARI EKSTRAK DAUN BINAHONG (Anredera cordifolin (Tenore) Steen)
}

\author{
Isabella Ramdha Y.P.M., Nur Azizah
}

Program Studi Farmasi, STIKes Muhammadiyah Kuningan

*E-mail : bellamanurung@gmail.com

\begin{abstract}
ABSTRAK
Spray gel atau gel semprot merupakan salah satu upaya pengembangan dalam sediaan bentuk topikal di farmasi. Kelebihan dari sediaan gel semprot yaitu memiliki tingkat kontaminasi mikroba yang rendah, lebih praktis dalam penggunannya dan waktu kontak obat yang relatif lebih lama dibandingkan dengan sediaan lainnya. Daun Binahong merupakan salah satu tanaman yang dapat digunakan untuk penyembuhan luka dengan senyawa yang terkandung berupa flavonoid, saponin, triterpenoid, alkaloid dan tannin. Tujuan penelitian ini untuk mengetahui apakah ekstrak daun binahong dapat dijadikan sebagai sediaan spray gel dan melihat kualitas sediaan dari evaluasi sediaan spray gel. Formulasi sediaan spray gel dibuat dengan menambahkan ekstrak daun binahong sebanyak $15 \%$. Hasil sediaan spray gel yaitu uji organoleptik yaitu memiliki sediaan berwarna coklat muda dengan bau khas dan terkstur yang agak kental, memiliki homogenitas yang baik dengan $\mathrm{pH}$ yang sesuai dengan standar yaitu 6 .Untuk uji pola penyemprotan $\mathrm{F} 1$ memiliki pola penyemprotan yang paling lebar dengan ratarata diameter yaitu jarak $3 \mathrm{~cm}(6,25 \mathrm{~cm})$, jarak $5 \mathrm{~cm}(4,85)$, jarak $10 \mathrm{~cm}(6,45 \mathrm{~cm})$, jarak $15 \mathrm{~cm}$ $(8,16 \mathrm{~cm})$ dan jarak $20 \mathrm{~cm}(8,28 \mathrm{~cm})$. Sedangkan hasil uji daya lekat terlihat pada $\mathrm{F} 3$ yang memiliki daya lekat lebih lama dan hasil uji viskositas menunjukkan bahwa semua formula tidak memenuhi standar viskositas sediaan spray gel.
\end{abstract}

Kata Kunci :Ekstrak daun binahong, Spray gel.

\section{ABSTRACT}

Spray gel or spray gel is one of the development efforts in topical forms in pharmaceuticals. The advantages of spray gel preparation is that they have a low level og microbial contamination, it is more practical in its use and the relatively longer contact time of the drug compared to other preparations. Binahong leaves are a plant that can be used for wound healing with compounds contained in the form of flavonoids, saponins, triterpenoids, alkaloids and tannins. The purpose of this study was to determine whether the extract binahong leaves can be used as a spray gel preparation and to see the quality of the preparation from the evaluation of spray gel preparations. The spray gel formulation is made by adding $15 \%$ binahong leaf extract. The result of the spray gel preparation is the organleptic test, which has a light brown color with a distinctive odor and a slightly thick texture, has good homogeneity with a $\mathrm{pH}$ that is in accordance with the standard, namely 6. For testing the spraying pattern F1 has the widest spraying pattern with an average The diameter is a distance of $3 \mathrm{~cm}(6.25 \mathrm{~cm})$, a distance of 5 cm (4.85), a distance

Keywords :Binahong leaf extract, Spray gel 


\section{PENDAHULUAN}

Luka adalah rusak atau hilangnya jaringan tubuh yang terjadi karena adanya suatu faktor yang mengganggu pada sistem perlindungan tubuh. Faktor pengganggunya yaitu seperti trauma, perubahan suhu, zat kimia, ledakan, sengatan listrik, atau gigitan hewan. Bentuk luka berbeda-beda tergantung dari penyebabnya, ada luka tertutup dan luka terbuka. Salah satu contoh luka terbuka yaitu luka sayat atau luka iris yaitu terdapat robekan linier pada kulit dan jaringan dibawahnya (Pusponegoro, 2005). Produk untuk mengobatidan pembersih lukayang telah beredar dipasaran yaitu hansaplast spray antiseptik yang memiliki kandungan kimia yaitu PHMB dan decyl glucoside tenside. Selain menggunakan obat yang mengandung bahan kimia, penyembuhan luka juga dapat diobati dengan menggunakan bahan alami salah satunya yaitu daun binahong.

Tanaman dengan nama ilmiah Anredera cordifolia (Tenore) Steenmemiliki khasiat diantaranya yaitu untuk menyembuhkan luka. Penelitian yang telah dilakukan oleh Rachmawati (2007) yaitu skrining fitokimia pada daun binahong menyatakan bahwa daun binahong mengandung senyawa kimia berupa saponin, triterpenoid, flavonoid dan minyak atsiri. Hasil dari penelitian yang dilakukan oleh Aried Eriadiet al (2013) bahwa ekstrak etanol daun binahong dapat digunakan untuk menyembuhkan luka sayat pada tikus putih jantan dengan dosis $5 \%$, $10 \%$ dan $15 \%$.

Penelitian lainnya juga menyatakan bahwa ekstrak daun binahong efektif untuk menyembuhkan luka sayat pada tikus putih dengan dosis yang paling efektif diberikan yaitu konsentrasi 30\% (Tresiaty, 2015). Berdasarkan penelitian yang dilakukan oleh Pebri et al (2017) bahwa ekstrak daun binahong dapat digunakan sebagai obat luka insisi yang mampu mempercepat proses penyembuhan pada luka. Mulai dari pengecilan ukuran luka, pengurangan intensitas warna kemerahan dan udema, pembentukan awal keropeng dan diakhiri dengan lepasnya keropeng. Proses penyembuhan luka dengan menggunakan ekstrak daun binahong tergantung pada konsentrasi ekstrak yang diberikan (Jauregui et al., 2009).

Salah satu bentuk dari pengembangan dalam sediaan gel untuk menutup luka yaitu dalam bentuk sediaan gel semprot (spray gel). Bentuk sediaan ini memiliki keuntungan yaitu dimana dengan teknik semprot memungkinkan sediaan yang dihantarkan ke luka tanpa harus melalui kontak dengan kapas, sehingga dapat meminimalkan limbah serta dapat mengurangi kontaminasi atau infeksi (Pebri et al., 2017).

Salah satu polimer yang dapat digunakan sebagai basis spray gel adalah karbopol atau carboxyvinyl, selain itu ada beberapa polimer yang telah dicoba sebagai pembentuk gel salah satunya yaitu HPMC (Kamishita, Takuzo et al.,1992). Karbopol merupakan salah satu pembentuk gel yang digunakan dengan konsentrasi yang kecil serta dapat menghasilkan gel dengan viskositas yang tinggi (Rowe, R.C., Paul, J.S., dan Marian, 2009). HPMC merupakan polimer semisintetik yang dapat membentuk gel yang jernih dan bersifat netral serta memiliki viskositas yang stabil pada penyimpanan jangka panjang (Rowe, R.C., Paul, J.S., dan Marian, 2009). Keunggulan karbopol dan HPMC yaitu dapat membentuk gel yang bening dan mudah larut dalam air.

Dari uraian diatas, maka penulis ingin melakukan penelitian mengenai formulasi sediaan Spray gel yang mengandung ekstrak daun binahong (Anredera cordifolia (Tenore) Steen) dengan dosis yang sudah terbukti dapat menyembuhkan luka yaitu $15 \%$.

\section{BAHAN DAN METODE}

\section{Bahan dan Alat}

Bahan yang digunakan dalam penelitian ini adalah Daun binahong, etanol $70 \%$, karbopol (PT. Dipa Persada Husda), HPMC (PT. Dipa Persada Husda), Trietanolamine (TEA) (PT. Dipa Persada Husda), propilen glikol (PT. Dipa Persada Husda), metil paraben (PT. Dipa Persada 
Husda), propil paraben (PT. Dipa Persada Husda), etanol 96\% (PT. Dipa Persada Husda) dan aquadetillata.

Alat yang digunakan yaitu wadah khusus untuk maserasi, gelas ukur (pyrex), corong (herma), batang pengaduk, watterbath, timbangan analitik (matrix), kain planel, mortir dan stemper (medizzy), spatel, kaca preparat, $\mathrm{pH}$ indikator universal, viskometer kapiler (SCHOTT) dan stopwatch.

\section{Jenis Penelitian}

Metodepenelitian yang dilakukanyaitusecaraeksperimentallaboratoriumuntukmemperoleh data hasil. Penelitianinidilakukandenganmembuat sediaan spray gel dari ekstrak daun binahong dengan konsentrasi dosis yang digunakan adalah 15\% dengan mengubah basis karbopol dan HPMC sebagai gelling agent pada setiap formulasi yaitu Karbopol dan HPMC pada formula A $0,4: 0,4$. formulasi $B$ 0,6:0,4 dan formula $C$ 0,4:0,6 yang kemudian sediaan ini dilihat kualitas sediaan nya dengan dilakukannya uji evaluasi sediaan.

\section{Prosedur Penelitian}

\section{Pengolahan Sampel}

Daun binahong diambil dari desa Jagabaya, Kuningan Jawa Barat. Kemudian dideterminasi di Laboratorium STIKes Muhammadiyah Kuningan. Bertujuan untukmengetahuikebenaranidentitas dari tanamantersebut.

Daun binahong yang diambil yaitu daun muda yang utuh, berwarna hijau dan masih segar. Kemudian sampel disortasi dan dibersihkan sampai bersih. Kemudian daun binahong dikeringkan menggunakan sinar matahari langsung, setelah daun binahong kering maka dihaluskan menggunakan blender sampai diperoleh serbuk daun binahong dan diayak dengan ayakan no.60.

\section{Pembuatan Ekstrak Daun Binahong}

Pembuatan ekstrak dilakukan dengan menggunakan metode maserasi menggunakan etanol $70 \%$ sesuai dengan literatur yaitu penelitian Aried Eriadiet al (2015). Masukan 250 gram serbuk kering simplisia kedalam toples kaca, kemudian tambahkan pelarut yaitu etanol $70 \%$ secukupnya dan dibiarkan selama 10 menit setelah semua serbuk simplisia terendam. Kemudian tambahkan pelarut hingga semua serbuk simplisia terendam. Diamkan selama 2 x 24 jam sambil sesekali diaduk. Kemudian ekstrak cair yang diperoleh saring dengan menggunakan kain flanel dan ditimbang berat yang didapatkannya. Hasil dari maserasi kemudian diuapkan dengan menggunakan waterbath hingga diperoleh ekstrak kental.

\section{Pembuatan Spray Gel}

Tabel 1. Pembuatan Spray Gel

\begin{tabular}{|c|c|c|c|c|}
\hline \multirow[t]{2}{*}{ Bahan } & \multicolumn{3}{|c|}{ Formula $(\%)$} & \multirow[t]{2}{*}{ Kegunaan } \\
\hline & F1 & F2 & F3 & \\
\hline Ekstrak Daun Binahong & 15 & 15 & 15 & Zat Aktif \\
\hline Karbopol & 0,4 & 0,6 & 0,4 & $\begin{array}{l}\text { Pembentuk Gel(Gelling } \\
\text { Agent) }\end{array}$ \\
\hline HPMC & 0,4 & 04 & 0,6 & $\begin{array}{l}\text { Pembentuk Gel } \\
\text { (Gelling Agent) }\end{array}$ \\
\hline Trietanolamine & 8 tetes & 10 tetes & 12 tetes & Pembasa \\
\hline Propilen Glikol & 15 & 15 & 15 & $\begin{array}{l}\text { Plasticizer dan } \\
\text { Humektan }\end{array}$ \\
\hline Metil Paraben & 0,18 & 0,18 & 0,18 & Pengawet \\
\hline Propil Paraben & 0,2 & 0,2 & 0,2 & Pengawet \\
\hline Etanol $96 \%$ & 20 & 20 & 20 & Pelarut \\
\hline Aquadestillata & Ad 100 & Ad 100 & Ad 100 & Pelarut \\
\hline
\end{tabular}


Pembuatan spray gel dilakukan dengan mendispersikan terlebih dahulu karbopol dengan menggunakan aquadestillata kemudian ditambah Trietanolamine hingga terbentuk massa gel transparan. Dalam mortir berbeda mendispersikan HPMC dengan menggunakan aquadestillata hingga terdispersi secara seluruhnya dan menjadi cairan bening dengan konsistensi yang cukup kental. Melarutkan pengawet (metil paraben \& propil paraben) dengan menggunakan etanol $96 \%$. Kemudian campurkan larutan HPMC dan larutan pengawet kedalam larutan karbopol aduk hingga homogen. Sediaan yang telah homogen kemudian tambahkan ekstak daun binahong yang sebelumnya telah didispersi dengan menggunakan etanol 96\% lalu aduk hingga terdispersi secara seluruhnya. Kemudian tambahkan aquadestillata hingga mencapai bobot yang diinginkan. Spray gel yang telah dihasilkan kemudian dimasukan kedalam botol spray.

\section{Evaluasi Sediaan}

\section{Uji Organoleptik}

Uji ini dilakukan dengan melakukan pengamatan pada warna, bau dan tekstur dari sediaan yang telah dibuat (Djajadisastra et al., 2009).

\section{Uji Homogenitas}

Sediaan gel dioleskan pada sekeping kaca preparat (transparan). Kemudian dilihat ada atau tidaknya partikel / zat yang belum tercampur secara homogen (Sudjono et al.,2012).

\section{Uji pH}

Uji pH dilakukan dengan menggunakan alat $\mathrm{pH}$ meter yang telah di kalibrasi (Sudjono et al.,2012).

\section{Uji Viksositas}

Uji viskositas dilakukan dengan menggunakan viskometer kapiler. Pengujian ini dilakukan dengan menghitung terlebih dahulu massa jenis pada tiap formula dengan menggunakan piknometer. Uji viskositas atau kekentalan ini memerlukan air sebagai cairan pembandingnya yang harga kekentalan nya telah diketahui $\eta_{1}=1,00 \mathrm{cps}$ ), maka diperoleh persamaan : (SuyudiS, 2014).

Keterangan :

$$
\frac{\eta 1}{\eta 2}=\frac{\rho 1 \times \mathrm{t} 1}{\rho 2 \times \mathrm{t} 2}
$$

$\eta 1=$ Kekentalan cairan yang ditentukan

$\eta 2=$ Kekentalan cairan yang diketahui kekentalannya

$\rho 1=$ densitas cairan yang akan diketahui

$\rho 2=$ densitas cairan yang telah diketahui

$\mathrm{t} 1$ = waktu yang dibutuhkan oleh cairan yang akan ditentukan

$\mathrm{t} 2$ = waktu yang dibutuhkan oleh cairan yang telah diketahui

\section{Uji Pola Penyemprotan}

Sediaan yang telah jadi disemprotkan pada selembar plastik yang telah diukur berat nya dan udah diberi nomor dengan jarak $3 \mathrm{~cm}, 5 \mathrm{~cm}, 10 \mathrm{~cm}, 15 \mathrm{~cm}$ dan $20 \mathrm{~cm}$. Kemudian diukur waktu mengering menggunakan stopwatch dan ditimbang setelah disemprotkan. Pengujian setiap jarak dilakukan secara triplo, pada pengujian ini yang diamati adalah pola pembentukan semprotan, diameter dari pola semprot yang terbentuk, dan banyaknya sediaan yang keluar (gram) setiap semprotnya dengan jarak yang sama (Suyudi. 2014).

\section{Uji Daya Lekat}

Pengujian ini dilakukan di kulit pada lengan bagian atas dan disemprotkan sediaan dari jarak $30 \mathrm{~mm}$ atau $3 \mathrm{~cm}$. Setelah disempotkan dihitung selama 10 detik untuk melihat apakah ada sediaan yang menempel atau tetesan dari hasil semprot menetes ke bawah (Kamishita T et al., 1992). 


\section{HASIL DAN PEMBAHASAN}

\section{Ekstraksi Daun Binahong}

Adapun hasil dari ekstraksi daun binahong didapatkan ekstrak dengan ciri-ciri yaitu cairan pekat berwarna hijau tua serta memiliki aroma khas daun binahong

Tabel 2.. Hasil Rendemen Ekstrak

\begin{tabular}{ccc}
\hline Berat awal simplisia & Berat hasil ekstrak & $\begin{array}{c}\text { \% Rendemen } \\
\text { ekstrak }\end{array}$ \\
\hline 164,62 gram & 116,82 gram & $70.96 \%$ \\
\hline
\end{tabular}

Dari hasil tabel 2. dapat dilihat bahwa rendemen eksrak daun binahong masih sangat besar persentase nya. Sehingga ekstrak yang dihasilkan pun menjadi ekstrak cair karena masih banyak pelarut yang terkandung didalamnya.

\section{Formulasi Spray Gel}

Alasan penggunaan kombinasi dua polimer yaitu karbopol dan HPMC adalah karena kombinasi dari kedua bahan ini dapat mempertahankan dan menghasilkan viskositas yang baik pada sediaan gel. HPMC itu sendiri merupakan gelling agent yang bersifat netral yang dapat membentuk gel yang jernih serta dapat mempertahankan viskositas gel yang dihasilkan, sedangkan untuk karbopol yaitu karena mudah terdispersi dalam air dan menghasilkan sediaan dengan viskositas yang cukup (Rowe,R.C.,2009).

Karbopol juga merupakan basis gel yang kuat dan aman untuk digunakan secara topikal karena tidak menimbulkan hipersensitivitas pada manusia serta melekat dengan baik (Draganoiu et al. 2009). Oleh karena itu bila dibandingkan dengan menggunakan basis tunggal maka keduanya dapat membentuk massa gel yang lebih baik secara fisik, viskositasnya tinggi, pelepasan obat dan disolusi yang baik serta bioavailibitas yang baik (Quinones dan Ghaly, 2008).

Trietanolamine disini digunakan sebagai agen pembasa (meningkatkan $\mathrm{pH}$ sediaan agar sediaan dapat mencapai $\mathrm{pH}$ yang sesuai dengan karakteristik $\mathrm{pH}$ kulit yaitu 4,5-6,5) (Tranggono and Latifah, 2007). Propilen glikol memiliki dua kegunaan yaitu plastizer dan humektan agar menjaga kelembaban atau kelembutan. Pengawet yang digunakan dalam formulasi ini yaitu kombinasi dua pengawet yaitu metil paraben dan propil paraben karena kombinasi kedua pengawet ini dapat menghasilkan aktivitas anti mikroba yang kuat dan alasan penggunaan pengawet dalam sediaan spray gel ini yaitu karena dalam sediaan ini terdapat kandungan air yang sangat tinggi sehingga dapat menimbulkan resiko kontaminasi mikroba yang tinggi. Oleh karena itu perlu ditambahkannya bahan pengawet pada formula (Bernardus, A.P.,2016).

\section{Evaluasi Sediaan}

\section{a. Uji Organoleptik}

Tabel 3. Hasil Evaluasi Organoleptik

\begin{tabular}{llll}
\hline & F1 & F2 & F3 \\
\hline Warna & Coklat & $\begin{array}{l}\text { Coklat } \\
\text { muda }\end{array}$ & Coklat \\
Bau & Khas & Khas & Khas \\
Tekstur & Agak & Agak & Agak \\
& encer & kental & kental \\
\hline
\end{tabular}

Perbedaan warna sediaan gel ini dipengaruhi oleh perbedaan konsentrasi karbopol dan HPMC dimana semakin tinggi karbopol maka akan terlihat lebih bening. Hasil ini sejalan dengan penelitian yang dilakukan oleh Suryani \& Teuku (2018) 


\section{b. Uji Homogenitas}

Pengujian homogenitas ini penting dilakukan karena sangat berpengaruh terhadap efektitas sediaan spray gel tersebut. Bila sediaan spray gel homogen maka dapat diasumsikan bahwa pada saat pemakaian atau pada saat pengambilan sediaan maka zat aktifnya itu seragam atau sama (Helmy A.,2018).

Dari hasil data pengamatan uji homogenitas menunjukan bahwa ketiga formula spray gel dari ekstrak daun binahong tersebut memiliki homogenitas yang baik, karena tidak adanya partikel yang tidak tercampur atau gel yang menggumpal dan tidak rata pada sediaan spray gel tersebut.

\section{c. Uji pH}

Pengujian $\mathrm{pH}$ menggunakan alat indikator universal. Uji $\mathrm{pH}$ ini dilakukan untuk mengetahui $\mathrm{pH}$ pada tiap formula yang dibuat. Nilai pH kulit yaitu 4,5-6,5 (Sudjono, T.A et al.,2012). pH tidak boleh terlalu asam karena dapat menyebabkan iritasi kulit dan tidak boleh juga terlalu basa karena dapat membuat kulit menjadi bersisik (Dureja, 2005, Vasiljevic.,2005 dalam Sharon, Nela.,Syariful Anam, Yuliet,2013).

Tabel 4. Hasi Evaluasi pH

\begin{tabular}{ll}
\hline Formula & Nilai pH \\
\hline Formula 1 & 6 \\
Formula 2 & 6 \\
Formula 3 & 6 \\
\hline
\end{tabular}

\section{d. Uji Viskositas}

Pengujian viskositas ini untuk melihat apakah sediaan spray gel dapat dihantarkan melalui aplikator. Viskositas yang terlalu encer akan menurunkan daya lekat gel pada kulit dan viskositas yang terlalu kental akan menimbulkan ketidak nyamanan saat sediaan tersebut digunakan. Persyaratan viskositas yang baik untuk spray gel yaitu kisaran 500-5000 cPs (Nisak, Khoirun 2016).

Tabel 5. Hasil Evaluasi Viskositas

\begin{tabular}{cc}
\hline Formula & $\begin{array}{c}\text { Nilai Viskositas } \\
\text { (cPs) }\end{array}$ \\
\hline Formula 1 & 0,043 \\
Formula 2 & 7,849 \\
Formula 3 & 14,381 \\
\hline
\end{tabular}

Berdasarkan hasil tabel 5 menunjukan bahwa ketiga formulasi tidak ada yang memenuhi persyaratan uji viskositas. Hal ini mungkin dikarenakan adanya penambahan eksrak daun binahong yang terlalu banyak karena semakin banyak penambahan ekstrak daun binahong maka akan semakin menurun nilai viskositas sediaan tersebut.

\section{e. Uji Pola Penyemprotan}

Pada uji ini yang diamati yaitu diameter terbentuknya pola penyemprotan dari setiap formula yang disemprotkan pada jarak yang sama. Pengujian ini dilakukan untuk melihat ukuran dari setiap pola semprotan.

Hasil pemeriksaan pola penyemprotan dari formula bervariasi, variasi dari sediaan spray gel dipengaruhi oleh jarak penyemprotan dan viskositas sediaan (Suyudi,2014). 


\section{f. Uji Daya Lekat}

Tabel 6. Hasil Evaluasi Daya Lekat

\begin{tabular}{cl}
\hline Formula & $\begin{array}{l}\text { Waktu } \\
\text { mengalir }\end{array}$ \\
\hline Formula 1 & 10 detik \\
Formula 2 & 11 detik \\
Formula 3 & 13 detik \\
\hline
\end{tabular}

Hasil pengujian menunjukan bahwa F1 mudah terjatuh dari punggung tangan lebih cepat dibanding F2 dan F3, hal ini dikarenakan sediaan F1 yang agak cair. Dari hasil ketiga formula dapat disimpulkan bahwa semakin besar HPMC yang digunakan maka akan mempengaruhi daya lekat pada sediaan (Suryani \& Teuku, 2018).

\section{SIMPULAN}

Dari hasil penelitian yang telah dilakukan maka dapat disimpulkan bahwa:

1. Ekstrak daun binahong dapat diformulasikan sebagai sediaan spray gel dengan menggunakan kombinasi karbopol dan HPMC sebagai polimer pembentuk gelling agent dengan melihat bentuk dari sediaan nya yang lebih encer dibandingkan dengan gel, hal ini dapat dilihat dari uji viskositas

2. Sediaan spray gel ekstak daun binahong dilihat dari evaluasi sediaan nya melalui uji organleptik yaitu memiliki sediaan berwarna coklat muda dengan bau khas dan terkstur yang agak kental, memiliki homogenitas yang baik dengan $\mathrm{pH}$ yang sesuai dengan standar yaitu 6 .Untuk uji pola penyemprotan F1 memiliki pola penyemprotan yang paling lebar dengan ratarata diameter yaitu jarak $3 \mathrm{~cm}(6,25 \mathrm{~cm})$, jarak $5 \mathrm{~cm}(4,85)$, jarak $10 \mathrm{~cm}(6,45 \mathrm{~cm})$, jarak 15 $\mathrm{cm}(8,16 \mathrm{~cm})$ dan jarak $20 \mathrm{~cm}(8,28 \mathrm{~cm})$. Sedangkan hasil uji daya lekat terlihat pada F3 yang memiliki daya lekat lebih lama dan hasil uji viskositas menunjukkan bahwa semua formula tidak memenuhi standar viskositas sediaan spray gel.

\section{REFERENSI}

Aried Eriadi, H. A. (2015). Pengaruh Ekstrak Etanol Daun Binahong (Anredera cordifolia (Tenore) Steen) Terhadap Penyembuhan Luka Sayat Pada Tikus Putih Jantan . Jurnal Farmasi Higea Vol.7 no.2

Bernardus, A. (2016). Optimasi Gelling Agent Carbopol 940 dan Humektan Sorbitol Dalam Formulasi Sediaan Gel Ekstrak Etanol Daun Binahong (Anredera cordifolia (Ten) Steeins). Fakultas Farmasi Universitas Sanata Dharma .

Djajadisastra, J. A. (2009). Formulasi Gel Topikal dari Ekstrak Nerii Folium dalam Sediaan Anti Jerawat. Jurnal Farmasi Indonesia, Vol 4(4).

Draganoiu, E. A. (2009). Handbook of Cosmetic Science and Technology, 110-113. London: Pharmaceutical Press.

Dureja, H. K. (2005). Cosmeceuticals : An Emerging Concept. Indian J Pharmacol .

Jauregui KM, G. J. (2009). A New Formolated Stable Papin-Pectin Aerosol Spray Skin Woundhealding. Biotechnology and Bioprocess Engineering, Vol.14 : 450-456.

Kamishitta, T. T. (1992). Spray Gel Base and Spray Gel Preparation Using Thereof . United State Patent Application Publication. America . 
Nisak, K. (2016). Naskah Publikasi : Uji Stabilitas Fisik dan Kimia Sediaan Gel Semprot Ekstrak Etanol. Tumbuhan Paku. SKRIPSI, UIN SYARIF HIDAYATULLAH JAKARTA

Pebri, I. G. (2017). Pengaruh Pemberian Ekstrak Daun Binahong (Anredera cordifolia) Terhadap Proses Penyembuhan Luka Insisi (Vulnus Incisivum) Pada Mencit (Mus musculus). Journal JIMVET.

Pusponegoro, A. (2005). Luka Dalam Ajar Ilmu Bedah Edisi ke-2. Jakarta: EGC, Penyunting : Sjamsuhidajat R, De Jong W.

Quinones, D. d. (2008). Formulation and Characterization of Nystatin Gel. Puerto Rico Health Science Journal, San Juan , 27(1), 61-67.

Rachmawati, D. S. (2007). Formulasi Krim Minyak Atsiri Rimpang Temu Giring (Curcuma beyneana) : Uji Sifat Fisik dan Daya Anti Jamur Terhadap Candida Albicans secara in vitro. Skripsi. Fakultas Farmasi Universitas Muhammadiyah Surakarta.

Rowe, R. P. (2009). Handbook Of Pharmaceutical Science 6th Edition. New York.

Sharon, N. S. (2013). Formulasi Krim Antioksidan Ekstrak Etanol Bawang Hutan (Eleutherine palmifolia L.Merr). Journal of Natural Science Vol.2(3) , 111-112.

Sudjono, T. M. (2012). Pengaruh Konsentrasi Gelling Agent Carbomer 934 dan HPMC Pada Formulasi Gel Lendir Bekicot (achatina Fulica) Terhadap Kecepatan Penyembuhan Luka Buka Pada Punggung Kelinci. PHARMACON : Jurnal Farmasi Indonesia Vol.13(1).

Suryani, T. T. (2018). Formulasi Gel Minyak Atsiri Sereh Dengan Basis HPMC dan Karbopol. Majalah Farmaseutik Vol.14(2) , 87-95.

Suyudi, S. D. (2014). Formulasi Gel Semprot Menggunakan Kombinasi Karbopol 940 dan HPMC sebagai Pembentuk Gel. Skripsi UIN Syarif Hidayatullah Jakarta.

Tranggono, R. I. (2007). Buku Pegangan Ilmu Pengetahuan Kosmetik. Jakarta: PT. Gramedia Pustaka Utama. hal.20.

Tresiaty, O. (2015). Pengaruh Pemberian Ekstrak Daun Binahong (Anredera cordifolia (Ten,) Steenis) Terhadap Gambaran Makroskopik Penyembuhan Luka Sayat Pada Tikus Putih (Rattus norvegicus). Skripsi. Program Studi Kedokteran Hewan Universitas Hassanudin

Vasiljevic, D. V. (2005). The Characterization Of The Semi-Solid W/O/W Emulsions With Low Concentratins Of The Primary Polymeric Emulsifier. Int J Cosmetic Sci . 